\title{
Thermal, structural and acetylation behavior of snail and periwinkle shells chitin
}

\author{
Oluwashina Philips Gbenebor ${ }^{1}$ - Emmanuel Isaac Akpan ${ }^{2}$. \\ Samson Oluropo Adeosun ${ }^{1}$
}

Received: 21 March 2017 / Accepted: 6 July 2017/Published online: 19 July 2017

(c) The Author(s) 2017. This article is an open access publication

\begin{abstract}
This article reports a successful removal of $\mathrm{CaCO}_{3}$ from snail and periwinkle shells for the purpose of producing high quality chitin for possible application as bio-fillers in bone fixation materials. Experiment was designed with varying concentrations of acid and alkali for demineralization, deproteinization and deacetylation of the samples. Thermal characteristics, morphology, degree of de-acetylation, crystalline structure and hydrogen bonding characteristics of the extracted chitin were examined. Infrared spectra, thermogravimetric analysis and X-ray diffraction patterns show that demineralization with $1.7 \mathrm{M}$ $\mathrm{HCl}$ led to a successful removal of $\mathrm{CaCO}_{3}$. Subsequent deproteinization and deacetylation with $1.2 \mathrm{M} \mathrm{NaOH}$ led to a development of chitosan having a degree of deacetylation of 77 and $60 \%$ for periwinkle and snail shells, respectively. Generally, all results show that different treatments led to different chitin structure and consequently different properties.
\end{abstract}

Keywords Chitin - Chitosan - Macromolecules · Deacetylation · Biofillers

Electronic supplementary material The online version of this article (doi:10.1007/s40204-017-0070-1) contains supplementary material, which is available to authorized users.

Emmanuel Isaac Akpan

emmanuel.akpan@ivw.uni-kl.de

1 Department of Metallurgical and Materials Engineering, University of Lagos, Lagos, Nigeria

2 Institut für Verbundwerkstoffe GmbH, 67663 Kaiserslautern, Germany

\section{Introduction}

Waste materials from food processing which occur in large quantities can lead to environmental and human health problems (Hamed et al. 2016). However, these wastes can be turned into high value useful products. Periwinkle and snail shells wastes like other Crustaceans and Molluscs contain some amounts of chitin (Maruthiah and Palavesam 2017; Rasti et al. 2017; Ramasamy et al. 2017; Hamdi et al. 2017; Ehrlich et al. 2017). This chitin can be extracted and used for applications such as cosmetics, preservatives (Farajzadeh et al. 2016), surgical sutures (Usman et al. 2016), bio-composites (Petrenko et al. 2017), papermaking, water purification (Al-Manhel et al. 2016), photography (Muzzarelli 1997), metal uptake from wastewater (Nair and Madhavan 1984; Peniche-Covas et al. 1992) and solid-state batteries (Arof et al. 1995).

Snail and periwinkle shells are abundant in Nigeria. Successful extraction of chitin from these sources would convert seemly waste shells to wealth. The chitin so extracted can find usefulness as fillers in bio-polymer composite materials. These biodegradable and biocompatible composites can be used as temporal fixation materials for bone implants. However, these shells have been reported (Isa et al. 2012) to contain very high amount of $\mathrm{CaCO}_{3}$ and this makes it difficult to obtain high purity chitin derivative from them.

This research was designed based on the following objectives: (1) to investigate the possibility of removing $\mathrm{CaCO}_{3}$ from snail and periwinkle shells of Nigerian origin, so as to successfully extract chitin (2) to study the progress of deacetylation of chitin from these sources by monitoring structural changes as the concentration of the reagents are changed, (c) to establish a synergy between acid and alkali concentrations that will lead to a combination of high DD, 
high crystallinity and good thermal stability of the chitin. A three level full factorial experimental design was used for the study.

\section{Materials and methods}

\section{Chitin extraction}

Shells of periwinkle [Tympanotonus fusatus (L.)] and snail [Achatina fulica (L.)] were scraped free of loose tissues, washed in water, dried and ground to $250 \mu \mathrm{m}$ in a ball mill. Demineralization was carried out at room temperature $\left(32{ }^{\circ} \mathrm{C}\right.$ ) by soaking $100 \mathrm{~g}$ of ground samples in $1.5,1.7$ and $1.9 \mathrm{M} \mathrm{HCl}$. For each concentration, the process was repeated several times until evolution of gaseous effluent ceased. The demineralized samples were washed with distilled water to neutral ( $\mathrm{pH} 7.0)$, filtered and dried in the oven at $70{ }^{\circ} \mathrm{C}$ for $4 \mathrm{~h}$ to constant weights. Deproteinization was conducted by heating demineralised samples in 0.4 , 0.8 and $1.2 \mathrm{M} \mathrm{NaOH}$ solutions in a beaker at $100{ }^{\circ} \mathrm{C}$ for $1 \mathrm{~h}$. Deproteinized samples were filtered and soaked in fresh sets of alkali solutions $(0.4,0.8$ and $1.2 \mathrm{M})$ for $18 \mathrm{~h}$ at room temperature $\left(32{ }^{\circ} \mathrm{C}\right)$ for effective protein removal. These samples were then washed in distilled water to neutrality and oven dried at $70{ }^{\circ} \mathrm{C}$. Depigmentation and bleaching was carried out by soaking the dried samples in $1 \mathrm{M} \mathrm{H}_{2} \mathrm{O}_{2}$ for $24 \mathrm{~h}$ at $32{ }^{\circ} \mathrm{C}$. The resulting samples were washed in distilled water and dried for $4 \mathrm{~h}$ in an oven at $70{ }^{\circ} \mathrm{C}$.

\section{X-ray diffraction (XRD)}

The XRD of the samples was conducted using PAN analytical X' Pert PRO MPD X-ray diffraction system PW3040/60 machine at Soochow University, Suzhou, China. Samples were exposed to a monochromatic $\mathrm{Cu} \mathrm{K \alpha}$ radiation $(\lambda=1.5406 \AA)$, operating at $40 \mathrm{kV}$ and $40 \mathrm{~mA}$. The samples were registered in a zero background sample holder to avoid external background interferences. The diffractograms were registered in the range of $7^{\circ}-90^{\circ}(2 \theta)$ in a step scan mode of 0.026261 at a counting time of $17.34 \mathrm{~s}$ per step.

\section{Fourier transform infrared spectroscopy (FTIR)}

A Nicolet $6700 \mathrm{M}$ spectrometer from Redeemers University, Ede, Nigeria, was used in carrying out FTIR spectra of samples in transmission mode. Ten milligram of fine samples were dispersed in a matrix of $\mathrm{KBr}(500 \mathrm{mg})$, followed by compression at 22-30 MPa to form pellets. The transmittance measurements were carried out in the range $400-4000 \mathrm{~cm}^{-1}$ at a resolution of $4 \mathrm{~cm}^{-1}$.

\section{Hydrogen bond}

Broad and overlapped FTIR absorption spectra existing between 3600 and $3000 \mathrm{~cm}^{-1}$ were resolved and improved by their deconvolution from a background scattering using a Gaussian function curve-fitting analysis with an $R^{2}>0.99$. The energy of the hydrogen bond $\mathrm{E}_{\mathrm{H}}$ (kcal) was calculated using Eq. 1 as adopted by Gbenebor et al. (2016).

$E_{\mathrm{H}}=\frac{1}{k}\left[\frac{v_{\mathrm{o}}-v}{v_{\mathrm{o}}}\right]$,

where $v_{\mathrm{o}}$ is the standard frequency corresponding to free OH groups $\left(3600 \mathrm{~cm}^{-1}\right) ; v$ is the frequency of the bonded $\mathrm{OH}$ groups and $k=1.68 \times 10^{-2} \mathrm{kcal}^{-1}$.

\section{Degree of deacetylation $(D D)$}

The degree of deacetylation (DD) of the chitin samples was calculated using the baselines proposed by Domszy and Roberts (1985) given in Eq. 2.

$\mathrm{DD}=100-\left[\frac{\left(A_{1655} / A_{3450}\right) \times 100}{1.33}\right]$

The $\mathrm{A}_{1655}$ and $\mathrm{A}_{3450}$ were the absorbance at $1655 \mathrm{~cm}^{-1}$ of the amide I band as a measure of the $\mathrm{N}$-acetyl group content and $3450 \mathrm{~cm}^{-1}$ of the hydroxyl band as an internal standard. The factor ' 1.33 ' is the ratio of $\mathrm{A}_{1655} / \mathrm{A}_{3450}$ for fully $\mathrm{N}$ acetylated chitin.

\section{Thermogravimetric analysis (TGA)}

In TGA, the change in mass of a sample is usually measured as a function of temperature or time under an inert (nitrogen) or oxidative (air) atmosphere. TGA was used to quantitatively determine the constituent of minerals and organic compound (including the biopolymer) in the samples. Analysis of samples was carried out on TGA Q500 instrument in Soochow University, Suzhou, China. $2 \mathrm{mg}$ of samples was heated to $750{ }^{\circ} \mathrm{C}$ at $10^{\circ} / \mathrm{min}$ heating rate. In this test, the temperature for the onset of thermal decomposition $\left(T_{\text {onset }}\right)$, the temperature at which decomposition rate was rapid $\left(T_{\max }\right)$, chitin content and yield were deduced from the thermograms.

\section{Scanning electron microscopy (SEM) with energy dispersive $\mathrm{X}$-ray analysis (EDS)}

An ASPEX 3020 model variable pressure SEM from Soochow University, Suzhou, China operated with an electron intensity beam $15 \mathrm{kV}$ and equipped with NoranVoyager energy dispersive spectroscope (EDS) was used to observe the morphological features of all samples. The 
samples to be observed under the SEM were mounted on a conductive carbon imprint left by the adhesive tape prepared by placing the samples on the circular holder and coated for $5 \mathrm{~min}$ to enable it conduct electricity.

\section{Results and discussion}

\section{De-acetylation progress of periwinkle shell chitin}

The process of de-acetylation involves the removal of acetyl groups from the molecular chain of chitin, leaving behind the amino group $\left(-\mathrm{NH}_{2}\right)$. Properties such as solubility, viscosity, ion-exchange capacity, flocculation ability, tensile strength, ability to chelate metal ions, immuneadjuvant activity and reaction with amino group are all dependent on DD (Zhang et al. 2011; Yuan et al. 2011; Kasaai 2009; Tan et al. 1998). FTIR was used to study the removal of acetyl groups and the development of amino group during de-acetylation of the samples. Figures 1a and
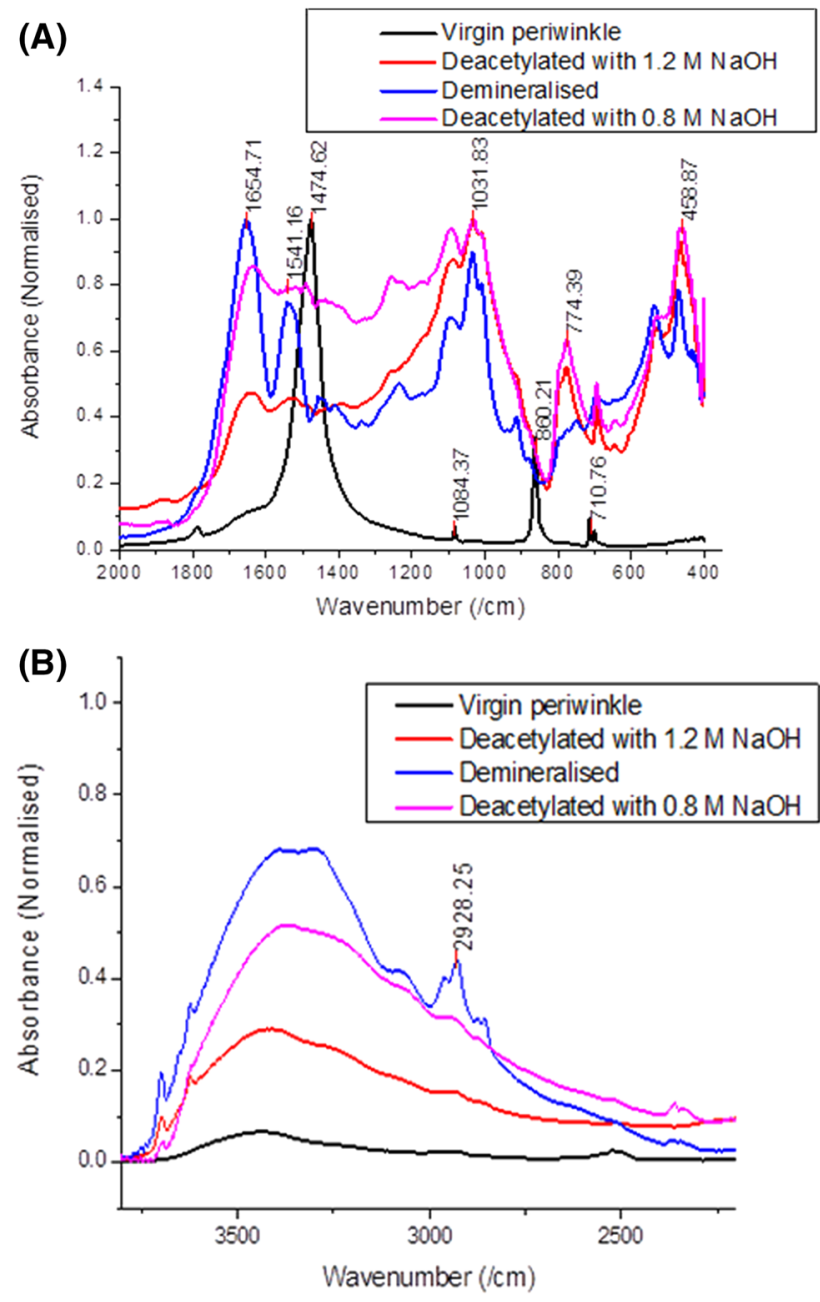

Fig. 1 De-acetylation progress of periwinkle shell chitin b show comparative FTIR spectra of samples with different treatment conditions. The figure reveals changes in the functional group with respect to treatment. The untreated sample shows the presence of bands at 1474 and $860 \mathrm{~cm}^{-1}$ indicating the presence of calcite (Gbenebor et al. 2016; Udomkan and Limsuwan 2008; Rahman and Halfar 2014). Other low intensity peaks also appear which have been associated with the presence of $\mathrm{CO}_{3}^{-2}$ (Aku et al. 2012). These peaks disappeared when the shells were acid treated, giving rise to a chitin structure (see Fig. 1a) with strong amide I and II peaks at 1654 and $1541 \mathrm{~cm}^{-1}$ (Kaya and Baran 2015).

The band between 2500 and $3600 \mathrm{~cm}^{-1}$ also greatly increased (see Fig. 1b). This increase is attributed to the increase in hydrogen bond energy. $\alpha$-chitin is known to possess strong inter-sheet and intra-sheet hydrogen bonding which is responsible for its stability and poor solubility (Rudall and Kenchington 1973; Khan et al. 2002). Other bands indicating the development of saccharide rings and $\mathrm{N}-\mathrm{H}$ stretching also appear after the acid treatment.

The spectrum of deproteinized samples reveals a marked reduction in the $\mathrm{C}=\mathrm{O}$ secondary amide stretch at $1654 \mathrm{~cm}^{-1}$ (amide I). However, the $\mathrm{N}-\mathrm{H}$ bend and $\mathrm{C}-\mathrm{N}$ stretch at $1541 \mathrm{~cm}^{-1}$ (amide II) increased. This is an indication that de-acetylation occurred leading to increase in amount of $\mathrm{NH}_{2}$ (This suggests an increase in DD). This scenario is supported by the decrease in the band between 2500 and $3600 \mathrm{~cm}^{-1}$ in Fig. 1b. It is widely believed that increase in DD is always accompanied by a decrease in inter-sheet and intra-sheet hydrogen bond energy.

It is also evident from Fig. 1a that increase in concentration of $\mathrm{NaOH}$ led to further decrease in $\mathrm{C}=\mathrm{O}$ secondary amide stretch at $1654 \mathrm{~cm}^{-1}$ (amide I). The $\mathrm{N}-\mathrm{H}$ bend, $\mathrm{NH}$ out of plane bending at $774 \mathrm{~cm}^{-1}$ and $\mathrm{C}-\mathrm{N}$ stretch at $1541 \mathrm{~cm}^{-1}$ (amide II) increases, indicating an increase in the amount of $\mathrm{NH}_{2}$. Figure $1 \mathrm{~b}$ shows a decrease in $\mathrm{OH}$ band height showing further decrease in hydrogen bonding. Table 1 shows the effect of change in concentration of alkali and acid on the values of DD. It is evident that

Table 1 Degree of de-acetylation of extracted chitin

\begin{tabular}{ll}
\hline Treatment conditions & DD (\%) \\
\hline $1.5 \mathrm{M} \mathrm{HCl}+0.4 \mathrm{M} \mathrm{NaOH}$ & 52 \\
$1.5 \mathrm{M} \mathrm{HCl}+0.8 \mathrm{M} \mathrm{NaOH}$ & 61 \\
$1.5 \mathrm{M} \mathrm{HCl}+1.2 \mathrm{M} \mathrm{NaOH}$ & 67 \\
$1.7 \mathrm{M} \mathrm{HCl}+0.4 \mathrm{M} \mathrm{NaOH}$ & 53 \\
$1.7 \mathrm{M} \mathrm{HCl}+0.8 \mathrm{M} \mathrm{NaOH}$ & 64 \\
$1.7 \mathrm{M} \mathrm{HCl}+1.2 \mathrm{M} \mathrm{NaOH}$ & 77 \\
$1.9 \mathrm{M} \mathrm{HCl}+0.4 \mathrm{M} \mathrm{NaOH}$ & 64 \\
$1.9 \mathrm{M} \mathrm{HCl}+0.8 \mathrm{M} \mathrm{NaOH}$ & 55 \\
$1.9 \mathrm{M} \mathrm{HCl}+1.2 \mathrm{M} \mathrm{NaOH}$ & 63 \\
\hline
\end{tabular}


increasing alkali concentrations led to increase in DD. This was not the case when acid concentration was increased.

\section{OH bonding for periwinkle shell chitin}

A careful analysis of the FTIR spectra (Fig. 1) show that all treated samples exhibited a splitting of the primary amide I band. This is a sufficient proof that the chitins obtained are $\alpha$ - structure (Sikorski et al. 2009; Wang et al. 2013). It is widely acknowledged that, $\alpha$-chitin is stabilized by two intra-molecular hydrogen bonds $(\mathrm{C}(3)-\mathrm{OH} \cdots \mathrm{O}-\mathrm{C}(5)$ and $\mathrm{C}(6)-\mathrm{OH} \cdots \mathrm{OC})$, and two intermolecular hydrogen bonds, $\mathrm{NH} \cdots \mathrm{OC}$ and $\mathrm{C}(6)-\mathrm{OH} \cdots \mathrm{OH}-\mathrm{C}(6)$ (Kameda et al. 2005; Minke and Blackwell 1978). In this study, the original FTIR spectra were broad and difficult to distinguish separately. Mathematical best fits were applied to the curves after normalization using the Gaussian function (Fig. 2). The fitting was performed until $R^{2}>0.998$ was obtained. Band assignment was performed according to the
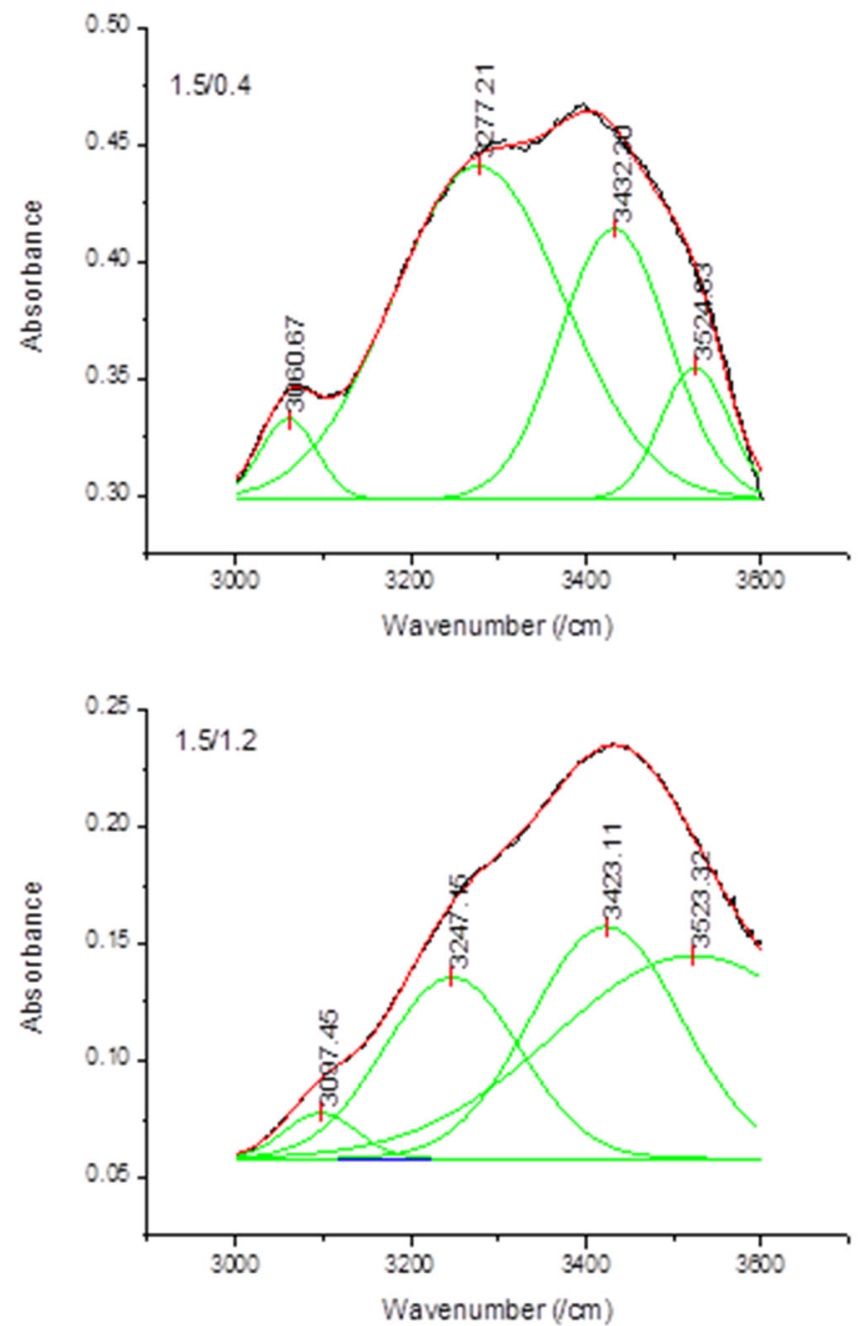

information obtained from Liu et al. (2010), Hu et al. (2007), Sikorski et al. (2009) and Kameda et al. (2005). The average content (\% proportion) of each band in the $\mathrm{OH}-$ band network was calculated in accordance to Gbenebor et al. (2016). Generally, it was observed that NH-OC and $\mathrm{C}(3) \mathrm{OH}-\mathrm{O}-\mathrm{C}$ bands were the dominant bands in the hydrogen bonding network. For $1.5 \mathrm{M} \mathrm{HCl} / 0.4 \mathrm{M} \mathrm{NaOH}$ (group I) treated samples, $\mathrm{NH}-\mathrm{OC}$ band occupied the largest proportion (57\%) of the entire $\mathrm{OH}$-band. In the case of $1.5 \mathrm{M} \mathrm{HCl} / 0.8 \mathrm{M} \mathrm{NaOH}$ (group II) treated samples $\mathrm{C}(3)-\mathrm{OH}-\mathrm{O}-\mathrm{C}$ occupied the largest proportion (49\%) of the entire $\mathrm{OH}-$ band. Similar to group I, NH-OC occupied the largest proportion (33\%) in $1.5 \mathrm{M} \mathrm{HCl} / 1.2 \mathrm{NaOH}$ (group III) samples. A similar trend was noticed in $1.7 \mathrm{M}$ $\mathrm{HCl}$ and $1.9 \mathrm{M} \mathrm{HCl}$ treated samples. A higher amount of these bands is an indication of higher stability. Table 2 shows that, the energy of the hydrogen bond $\left(E_{\mathrm{H}}\right)$ was higher for intermolecular bonds compared to intra-molecular bonds.

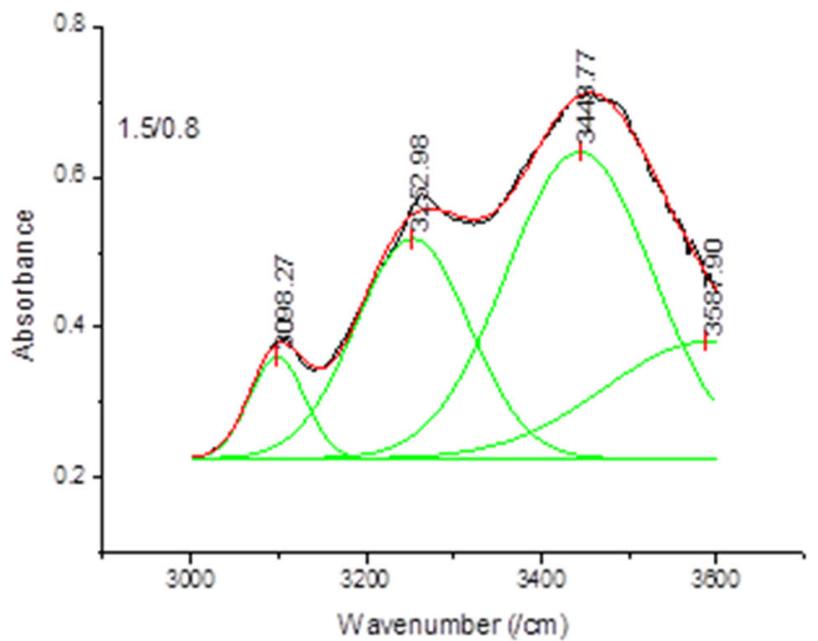

Fig. $2 \mathrm{OH}$ bonding for treated periwinkle chitin with $1.5 \mathrm{M} \mathrm{HCl}$ (figures for 1.7 and $1.9 \mathrm{M} \mathrm{HCl}$ treated samples are given in supplementary data file) 
Table 2 Inter-sheet hydrogen bond energy for periwinkle shell chitin

\begin{tabular}{lllll}
\hline & Sample treatment & $\begin{array}{l}\mathrm{C}(6)-\mathrm{OH} \cdots \mathrm{OH}-\mathrm{C}(6) \\
\text { Bond energy (kcal) }\end{array}$ & $\begin{array}{l}\mathrm{C}(3)-\mathrm{OH} \cdots \mathrm{O}-\mathrm{C}(5) \\
\text { Bond energy (kcal) }\end{array}$ & $\begin{array}{l}\text { Average bond energy } \\
\text { Bond energy (kcal) }\end{array}$ \\
\hline 1. & $1.5 \mathrm{M} \mathrm{HCl}+0.4 \mathrm{M} \mathrm{NaOH}$ & 8.92 & 2.77 & 11.69 \\
2. & $1.5 \mathrm{M} \mathrm{HCl}+0.8 \mathrm{M} \mathrm{NaOH}$ & 8.30 & 2.58 & 10.88 \\
3. & $1.5 \mathrm{M} \mathrm{HCl}+1.2 \mathrm{M} \mathrm{NaOH}$ & 8.31 & 2.92 & 11.23 \\
4. & $1.7 \mathrm{M} \mathrm{HCl}+0.4 \mathrm{M} \mathrm{NaOH}$ & 9.18 & 2.81 & 11.99 \\
5. & $1.7 \mathrm{M} \mathrm{HCl}+0.8 \mathrm{M} \mathrm{NaOH}$ & 8.26 & 3.24 & 11.50 \\
6. & $1.7 \mathrm{M} \mathrm{HCl}+1.2 \mathrm{M} \mathrm{NaOH}$ & 8.14 & 2.95 & 11.09 \\
7. & $1.9 \mathrm{M} \mathrm{HCl}+0.4 \mathrm{M} \mathrm{NaOH}$ & 8.85 & 3.25 & 12.10 \\
8. & $1.9 \mathrm{M} \mathrm{HCl}+0.8 \mathrm{M} \mathrm{NaOH}$ & 9.26 & 3.02 & 12.28 \\
9. & $1.9 \mathrm{M} \mathrm{HCl}+1.2 \mathrm{M} \mathrm{NaOH}$ & 8.57 & 2.99 & 11.56 \\
\hline
\end{tabular}

It is widely acknowledged that inter-sheet and intrasheet hydrogen bonding is responsible for basic chitin properties such as solubility, crystallinity and strength (Kurita et al. 1994; Kurita et al. 1990; Kurita et al. 1993b; Kurita et al. 1993a; Rudall and Kenchington 1973). However, out of the four hydrogen bonds (Liu et al. 2010; Hu et al. 2007; Sikorski et al. 2009; Kameda et al. 2005) identified in chitin, $\mathrm{C}(3)-\mathrm{OH} \cdots \mathrm{O}-\mathrm{C}(5)$ and $\mathrm{C}(6)-\mathrm{OH} \cdots \mathrm{OC}$ are known to be responsible for the stability, solubility and crystallinity (Gbenebor et al. 2016). The average bond energy of these bonds is a measure of the intra-sheet bond strength. This bond energy can be used as a relative measure of the effect of treatment on chitin structure. Therefore, the best combination of treatment to achieve desired properties can be determined by (1) understanding the development of this bond energy, and (2) correlating the bond strength with DD. Table 2 shows the average intrasheet bond energy. The average bond energy was found to decrease with increase in alkali concentration. It is also important to note that higher concentration of acid leads to higher hydrogen bond energy. On the other hand, samples with higher DD exhibits relatively lower average bond energy.

\section{Crystalline structure of periwinkle chitin}

Figure 3 shows the X-ray diffraction patterns of untreated periwinkle shell and extracted chitins. The figure shows that prominent chitin peaks were developed after treatments. The diffraction peaks at 27.07, 35.84 and 42.72 in the virgin sample are crystalline diffractions from calcite (Mikkelsen et al. 1997; Heredia et al. 2007). These peaks are not present in the treated samples, showing that the treatment was successful in removing $\mathrm{CaCO}_{3}$ from the shells. The XRD patterns for treated samples show two sharp crystalline reflections at $20.6^{\circ}$ and $26.4^{\circ}$ which are typical reflections of de-acetylated chitin (Cho et al. 2000; Jang et al. 2004; Yen et al. 2009; Sajomsang and Gonil

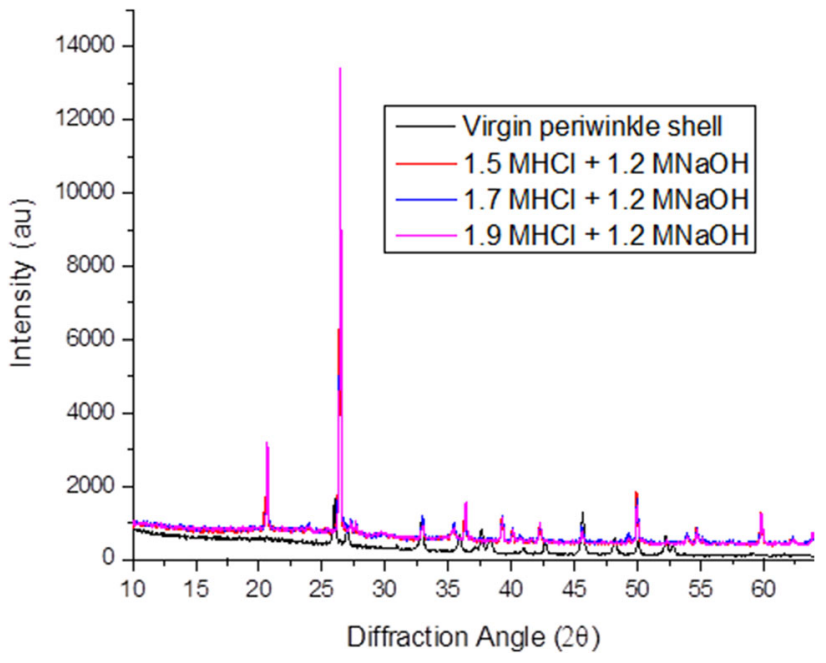

Fig. 3 XRD of virgin periwinkle and selected chitin samples

2010; Gonil and Sajomsang 2012; La Juárez-de Rosa et al. 2012). Peaks occurring in the $20.5-20.8^{\circ}$ range are attributed to (020) of chitosan and the peaks in the 26.3-26.6 diffraction range are attributed to (013) of $\alpha$-chitin. This indicates that the treated samples contain a combination of chitin and chitosan. The figure also shows that different treatment led to different diffraction intensities. This is an indication of difference in structure of the samples due to difference in treatment.

\section{Thermal properties of periwinkle chitin}

Thermal stability is a critical factor for the determination of potential applications of chitin and its derivatives. Chitin requires high thermal energy for dissociation of its crystalline structure. This makes thermal characterization an important aspect of chitin characterization (Wang et al. 2013). This section deals with the effect of treatment on the thermal behavior of chitin extracted from periwinkle shell. Figures 4 and 5 are representative TGA and DTG curves of 


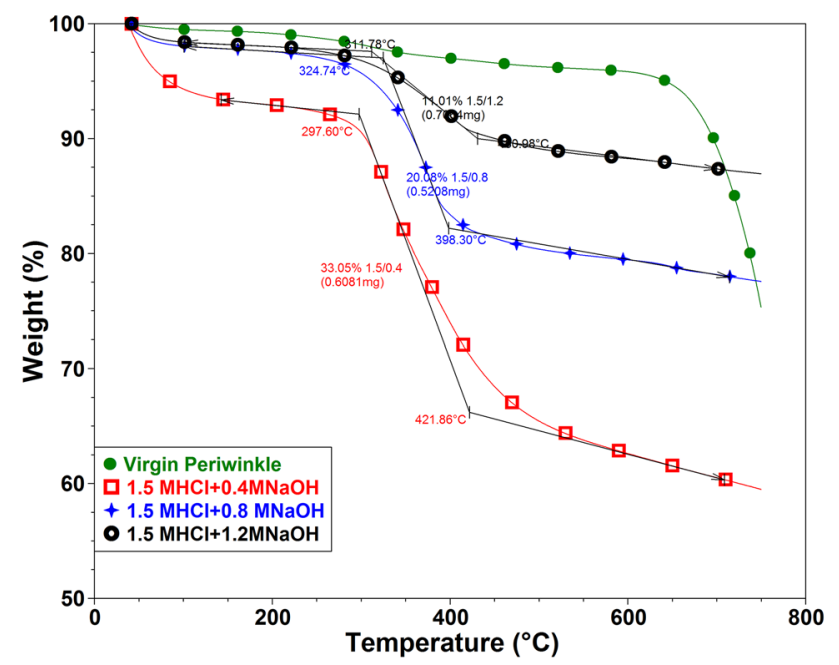

Fig. 4 TGA of periwinkle chitin treated with $1.5 \mathrm{M} \mathrm{HCl}$ and varying alkali concentration (other TGA figures are shown in the supplementary data file)

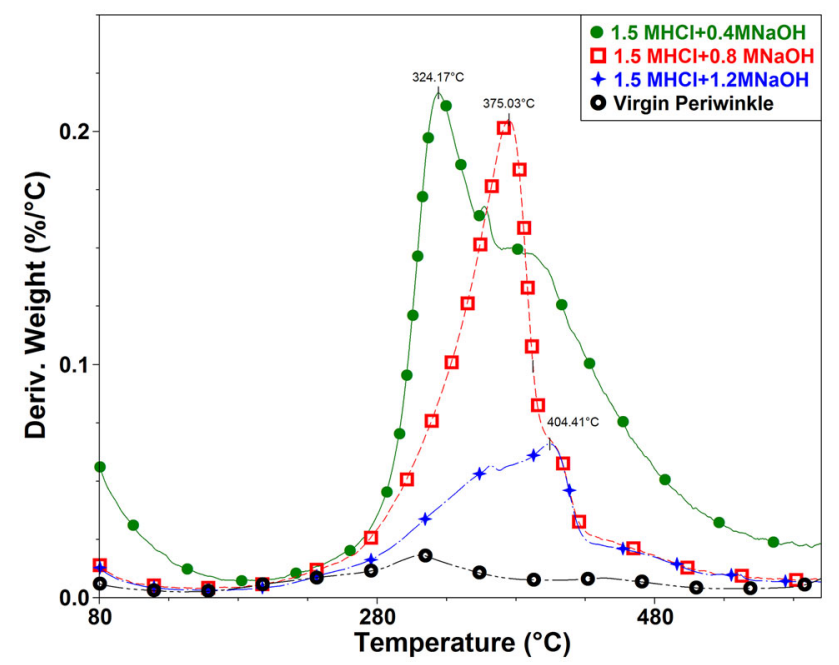

Fig. 5 DTG of periwinkle chitin treated with $1.5 \mathrm{M} \mathrm{HCl}$ and varying alkali concentration treated and virgin samples. Figure 4 shows that the thermal degradation of $1.5 \mathrm{M} \mathrm{HCl}$ treated samples proceed in two stages. This is typical of chitin extracted from natural sources (Abdou et al. 2008; Jang et al. 2004; Paulino et al. 2006; Sagheer et al. 2009; Wanjun et al. 2005). The first weight loss which occurred between 30 and $100{ }^{\circ} \mathrm{C}$ is attributed to the loss of absorbed or bounded water (Zakaria et al. 2012). This accounted for 4.35, 0.48 and $0.73 \%$ weight loss in $0.4,0.8$ and $1.2 \mathrm{M} \mathrm{NaOH}$-treated samples, respectively. These values are quite small compared to those obtained by (Kaya et al. 2013; Kaya et al. 2015a; Kaya et al. 2014; Zakaria et al. 2012; Shigemasa et al. 1996; Sajomsang and Gonil 2010; Sagheer et al. 2009; La Juárez-de Rosa et al. 2012).

The second stage of degradation occurs between 290 and $430{ }^{\circ} \mathrm{C}$ with 33,20 and $11 \%$ weight loss as for $0.4,0.8$ and $1.2 \mathrm{M} \mathrm{NaOH}$-treated samples, respectively. This decomposition is attributed to the decomposition of saccharide backbones, polymerization and decomposition of acetylated and deacetylated units of chitin (Sajomsang and Gonil 2010; Sagheer et al. 2009). The onsets of degradation for 0.4, 0.8 and 1.2 M NaOH-treated samples are 297, 324 and $311^{\circ} \mathrm{C}$, respectively. The $\mathrm{DTG}_{\max }$ of $0.4,0.8$ and 1.2 M NaOH-treated samples are 324, 375 and $404{ }^{\circ} \mathrm{C}$, respectively (Fig. 5). Jang et al. (2004) recorded similar values for alpha and beta chitin in their study. The difference in the peak temperature is attributed to the difference in intermolecular hydrogen bonds of the samples. This indicates a difference in structure as also seen in results of the FTIR presented in previous section. Thermal decomposition activation energies are 60.83, 50.13 and $54.05 \mathrm{~kJ} \mathrm{~mol}^{-1}$ for $0.4,0.8$ and $1.2 \mathrm{M} \mathrm{NaOH}$-treated samples, respectively. Generally, the $0.8 \mathrm{M} \mathrm{NaOH}$-treated samples shows the best thermal stability. A similar trend was noted in 1.7 and $1.9 \mathrm{M} \mathrm{HCl}$ treated samples. However, differences in activation energy, onset of degradation and peak degradation temperatures were noted (Table 3 ). These differences, proves the difference in structure of the treated

Table 3 Thermal properties of periwinkle chitin

\begin{tabular}{|c|c|c|c|c|c|c|}
\hline Sample & Activation energy & Residue at $600{ }^{\circ} \mathrm{C}$ & DTG2 (\%) & Water $(\%)$ & DTGmax & Onset temp \\
\hline $1.5 \mathrm{M} \mathrm{HCl}+0.4 \mathrm{M} \mathrm{NaOH}$ & 60.83 & 62.60 & 33.05 & 4.35 & 324.17 & 297.06 \\
\hline $1.5 \mathrm{M} \mathrm{HCl}+0.8 \mathrm{M} \mathrm{NaOH}$ & 50.13 & 79.44 & 20.08 & 0.48 & 375.03 & 324.00 \\
\hline $1.5 \mathrm{M} \mathrm{HCl}+1.2 \mathrm{M} \mathrm{NaOH}$ & 54.05 & 88.26 & 11.01 & 0.73 & 404.41 & 311.78 \\
\hline $1.7 \mathrm{M} \mathrm{HCl}+0.4 \mathrm{M} \mathrm{NaOH}$ & 66.61 & 69.46 & 27.56 & 2.98 & 343.78 & 306.00 \\
\hline $1.7 \mathrm{M} \mathrm{HCl}+0.8 \mathrm{M} \mathrm{NaOH}$ & 9.23 & 91.17 & 8.04 & 0.79 & 382.90 & 327.52 \\
\hline $1.7 \mathrm{M} \mathrm{HCl}+1.2 \mathrm{M} \mathrm{NaOH}$ & 68.29 & 87.31 & 11.85 & 0.84 & 388.17 & 327.75 \\
\hline $1.9 \mathrm{M} \mathrm{HCl}+0.4 \mathrm{M} \mathrm{NaOH}$ & 61.52 & 51.92 & 41.20 & 6.88 & 318.50 & 296.35 \\
\hline $1.9 \mathrm{M} \mathrm{HCl}+0.8 \mathrm{M} \mathrm{NaOH}$ & 51.24 & 77.30 & 20.56 & 2.14 & 395.05 & 337.74 \\
\hline $1.9 \mathrm{M} \mathrm{HCl}+1.2 \mathrm{M} \mathrm{NaOH}$ & 44.41 & 84.61 & 12.06 & 3.33 & 390.39 & 346.41 \\
\hline
\end{tabular}


Fig. 6 SEM/EDS images of periwinkle shell chitin a untreated, b acid treated $\mathbf{c} 1.9$ $\mathrm{M} \mathrm{HCl} / 0.8 \mathrm{M} \mathrm{NaOH}$ treated
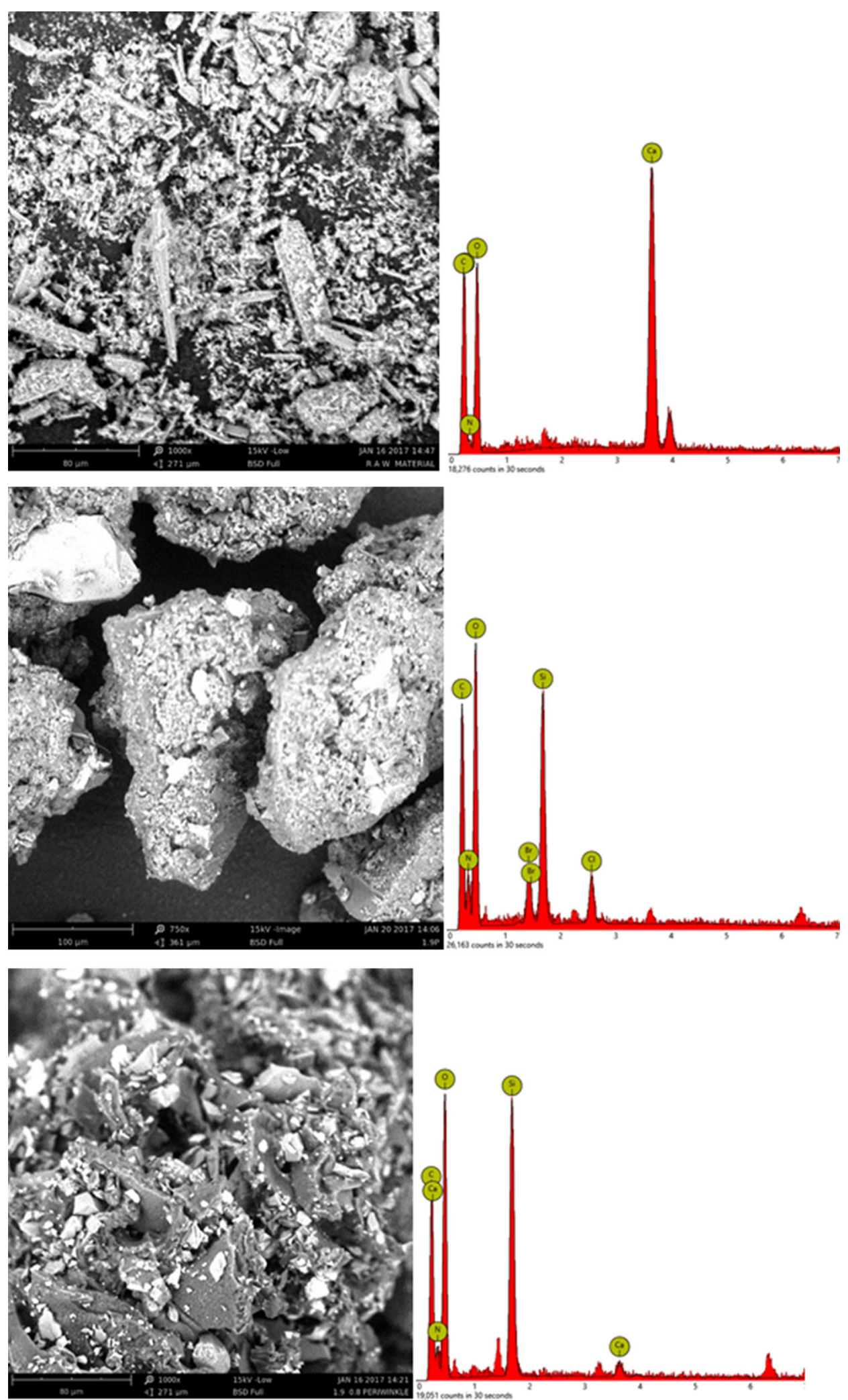

samples which has been attributed to the difference in treatment conditions.

Generally, it is noted that samples treated with $0.4 \mathrm{M}$ $\mathrm{NaOH}$ present a DTG with two or more peaks in the second degradation stage. This behavior was also noted by Georgieva et al. (2012). They suggested that the first peak is associated with thermal depolymerisation of chitin and the formation of volatile low molecular weight product 
whereas the second peak is attributed to oxidative thermal degradation of formed char. This occurrence confirms the difference in degradation behavior of chitin extracted with different treatment conditions. On the other hand, it is also noted that in all cases samples treated with $0.4 \mathrm{M} \mathrm{NaOH}$ possess the highest and broadest peak.

\section{Surface morphology of chitin extracted from periwinkle shell}

Changes in surface morphology of the chitin in relation to treatment conditions are shown in Fig. 6. Figure 6a is the SEM image of raw periwinkle shell. The image shows nonuniform sized particles with rough surfaces. The rough surface is an indication of the prevalence of $\mathrm{CaCO}_{3}$ in the parent material. As shown in the EDS, calcium-related compounds constitute the highest percentage in the tested sample. Demineralised sample (Fig. 6b) shows agglomeration with evidence of the development of fibrillar structure. The fibrillar structure is attributed to the high $\mathrm{OH}$ bonding in the extracted chitin. The EDS shows the absence of calcium in the demineralised sample. This shows that demineralisation led to removal of the $\mathrm{CaCO}_{3}$. The EDS also show increase in carbon and hydrogen content. This confirms the development of chitin structure. Figure $6 \mathrm{c}$ shows the effect deacetylation with $0.8 \mathrm{M}$ $\mathrm{NaOH}$. The images shows plate-like micro-fibrillar structure changes to globular structure. This indicates the action of deacetylation.

\section{De-acetylation progress of snail chitin}

Figures $7 \mathrm{a}$ and $\mathrm{b}$ show the difference in FTIR spectra of untreated and treated snail shells. The starting material (untreated sample) show prominent absorptions peaks at 1477 and $863 \mathrm{~cm}^{-1}$. These are attributed to $\mathrm{CaCO}_{3}$ adsorption (Gbenebor et al. 2016; Udomkan and Limsuwan 2008; Rahman and Halfar 2014). Other low intensity peaks also appear at 1786 and $714 \mathrm{~cm}^{-1}$, which are attributed to the presence of $\mathrm{CO}_{3}^{-2}$ (Udomkan and Limsuwan 2008). It is evident from the figure that these peaks are absent in the spectra of all treated samples. The absence of these peaks is an indication of the effectiveness of the demineralisation process to remove the unwanted $\mathrm{CaCO}_{3}$. The spectrum of demineralized sample show the presence of polysaccharide rings, secondary amides and NH links (1660, 1554, 1078, $464 \mathrm{~cm}^{-1}$, etc.). This indicates the development of chitin structure (Kaya and Baran 2015; Kaya et al. 2015b; Kaya et al. 2014). The N-H and O-H stretching (3100-3600 cm range) experienced an increase in peak height after demineralization. Subsequent treatment with $0.8 \mathrm{M} \mathrm{NaOH}$ brought about a marked change in amide I, II and O-H, N-H bands.
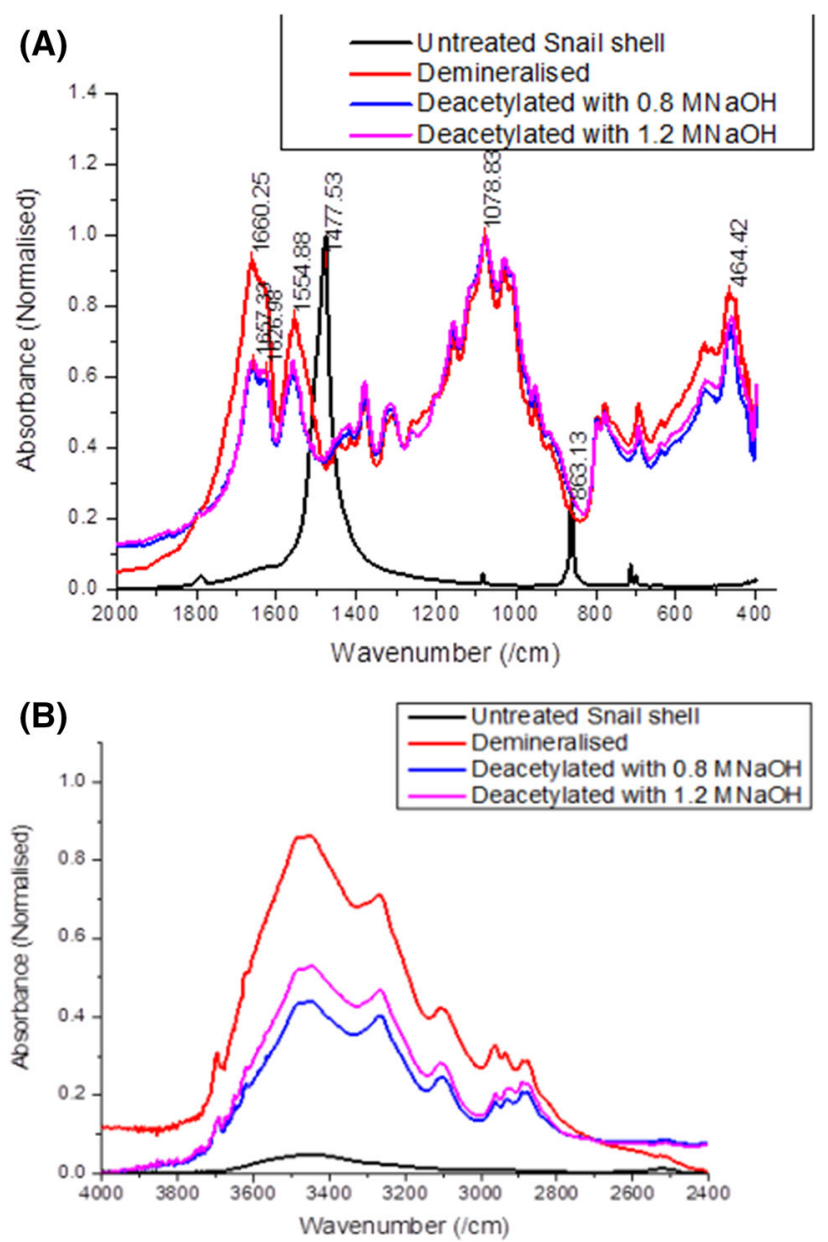

Fig. 7 De-acetylation Progress of periwinkle shell chitin

The secondary amide I band at $1660 \mathrm{~cm}^{-1}$ and the amide II band at $1554 \mathrm{~cm}^{-1}$ experience significant decrease. The amide I band broke into two low frequency bands (1657 and $1626 \mathrm{~cm}^{-1}$ ). The splitting of this band indicates that the treated sample is an alpha structure chitin. The figure also shows that $\mathrm{O}-\mathrm{H}, \mathrm{N}-\mathrm{H}$ bands $\left(3100-3600 \mathrm{~cm}^{-1}\right)$ narrows and decrease markedly after treatment with $0.8 \mathrm{M} \mathrm{NaOH}$. This is an indication that deacetylation led to a decrease in inter/intra sheet H-Bond energy. Further treatment with 1.2 $\mathrm{M} \mathrm{NaOH}$ did not produce so much change in the spectra except a marginal change in the height of $\mathrm{O}-\mathrm{H}, \mathrm{N}-\mathrm{H}$ bands. This indicates that further de-acetylation led to a slight change in the structure, which may be attributed to depolymerisation of the polysaccharide.

\section{OH bonding for snail shell chitin}

The results of spectral fitting of the $\mathrm{OH}$ broad band of snail shell chitin samples are shown in Fig. 8. Samples treated with $1.5 \mathrm{M} \mathrm{HCl} / 0.4 \mathrm{M} \mathrm{NaOH}$ show inter and intramolecular bonds of $\mathrm{C}(6)-\mathrm{OH} \cdots \mathrm{OH}-\mathrm{C}(6), \mathrm{NH} \cdots \mathrm{OC}, \mathrm{C}(3)-$ $\mathrm{OH} \cdots \mathrm{O}-\mathrm{C}(5)$ and $\mathrm{C}(6)-\mathrm{OH} \cdots \mathrm{OC}$ at $3098,3258,3440$ and 
$3537 \mathrm{~cm}^{-1}$, respectively. For this sample, $\mathrm{C}(3)-\mathrm{OH} \cdots \mathrm{O}-$ $\mathrm{C}(5)$ is found to occupy the highest proportion $(42.68 \%)$ of the entire $\mathrm{OH}$ bond. The higher proportion of the $\mathrm{C}(3)-$ $\mathrm{OH} \cdots \mathrm{O}-\mathrm{C}(5)$ intra chain bonding is an indication of superior chain stability (Kumirska et al. 2010). An increase in alkali concentration to $0.8 \mathrm{M} \mathrm{NaOH}$ brought a decrease in the proportion of $\mathrm{C}(3)-\mathrm{OH} \cdots \mathrm{O}-\mathrm{C}(5)$ to $22.59 \%$, but significant increase in the $\mathrm{C}(6)-\mathrm{OH} \cdots \mathrm{OC}(52.92 \%)$. However, the proportions of $\mathrm{NH} \cdots \mathrm{OC}$ and $\mathrm{C}(6)-\mathrm{OH} \cdots \mathrm{OH}-\mathrm{C}(6)$ inter chains decreased. This decrease points to increase in DD (Cho et al. 2000). A further increase in alkali concentration to $1.2 \mathrm{M} \mathrm{NaOH}$ gave a profound increase in $\mathrm{C}(3)-\mathrm{OH} \cdots \mathrm{O}-\mathrm{C}(5)$ intra chain bonds $(51.15 \%)$.

Increase in acid concentration to $1.7 \mathrm{M}$ presents a slightly different result. The $\mathrm{C}(3)-\mathrm{OH} \cdots \mathrm{O}-\mathrm{C}(5)$ inter-chain is found to dominate the $\mathrm{OH}$ bonding in all cases. Treatment with $0.4,0.8$ and $1.2 \mathrm{M} \mathrm{NaOH}$ resulted in 61,58 , and $66 \%$ of $\mathrm{C}(3)-\mathrm{OH} \cdots \mathrm{O}-\mathrm{C}(5)$, respectively. However, the relative proportion of $\mathrm{C}(6)-\mathrm{OH} \cdots \mathrm{OH}-\mathrm{C}(6)$ and $\mathrm{NH} \cdots \mathrm{OC}$ was lower in all cases. The low amount of these bonds implies that samples undergo transformation from anti-parallel to parallel sheet arrangement, which point to increase in DD. This is evident in Table 4 which reveals that the DD of these samples are slightly $>50 \%$ (Kumirska et al. 2010).

Spectral fittings for samples treated with higher acid concentration $(1.9 \mathrm{M})$ indicates that the treatment produced slight decrease in the amount of $\mathrm{C}(3)-\mathrm{OH} \cdots \mathrm{O}-\mathrm{C}(5)$ in all cases and a slight increase in amount of $\mathrm{NH} \cdots \mathrm{OC}$ and $\mathrm{C}(6)-\mathrm{OH} \cdots \mathrm{OH}-\mathrm{C}(6)$ in all cases. Thus, further increase in acid concentration does not produce significant changes. Table 5 shows the inter-sheet hydrogen bonding energy for snail shell chitin. The average hydrogen bond energy did not differ significantly from each other. However, comparing Tables 4 and 5, it is deduced that treatment combination that produces higher DD also leads to relatively lower average bond energy.
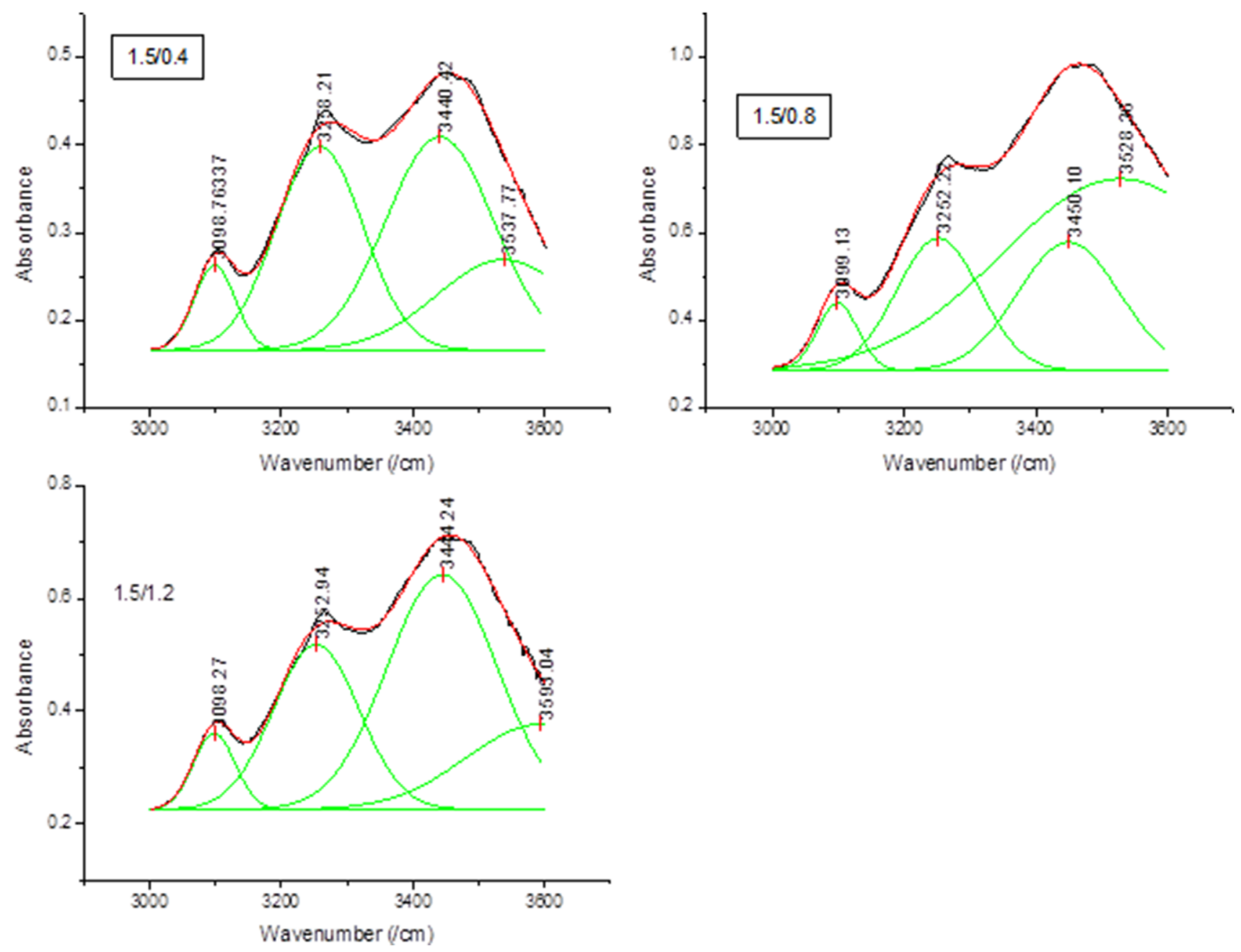

Fig. $8 \mathrm{OH}$ bonding for snail chitin treated with $1.5 \mathrm{M} \mathrm{HCl}$ and a $0.4, \mathbf{b} 0.8$ and $\mathbf{c} 1.2 \mathrm{M} \mathrm{NaOH}$ (figures for samples treated with 1.7 and $1.9 \mathrm{M}$ $\mathrm{HCl}$ are given in the supplementary data file) 
Table 4 Degree of deacetylation of chitin extracted from snail shell

\begin{tabular}{ll}
\hline Sample treatment & DD (\%) \\
\hline $1.5 \mathrm{M} \mathrm{HCl}+0.4 \mathrm{M} \mathrm{NaOH}$ & 53 \\
$1.5 \mathrm{M} \mathrm{HCl}+0.8 \mathrm{M} \mathrm{NaOH}$ & 51 \\
$1.5 \mathrm{M} \mathrm{HCl}+1.2 \mathrm{M} \mathrm{NaOH}$ & 60 \\
$1.7 \mathrm{M} \mathrm{HCl}+0.4 \mathrm{M} \mathrm{NaOH}$ & 52 \\
$1.7 \mathrm{M} \mathrm{HCl}+0.8 \mathrm{M} \mathrm{NaOH}$ & 58 \\
$1.7 \mathrm{M} \mathrm{HCl}+1.2 \mathrm{M} \mathrm{NaOH}$ & 56 \\
$1.9 \mathrm{M} \mathrm{HCl}+0.4 \mathrm{M} \mathrm{NaOH}$ & 50 \\
$1.9 \mathrm{M} \mathrm{HCl}+0.8 \mathrm{M} \mathrm{NaOH}$ & 46 \\
$1.9 \mathrm{M} \mathrm{HCl}+1.2 \mathrm{M} \mathrm{NaOH}$ & 56 \\
\hline
\end{tabular}

\section{Crystalline structure of snail chitin}

The XRD patterns for virgin snail shell and extracted chitin samples are shown in Fig. 9. $\mathrm{CaCO}_{3}$ crystalline diffraction peaks are shown in the virgin samples at 27.32, 33.23, 36.29 and 43.07 (Heredia et al. 2007; Mikkelsen et al. 1997). These peaks are absent in the extracted chitin showing that the treatment was successful in removing $\mathrm{CaCO}_{3}$ from the shells. The XRD patterns of treated samples show prominent peaks between $20^{\circ}$ and $21^{\circ}$ and $26^{\circ}-27^{\circ}$. A broad peak is also shown between $18^{\circ}$ and $19^{\circ}$ for the treated samples. A similar XRD pattern has been reported for crab, shrimp, krill and insects in earlier studies (Yen et al. 2009; Sajomsang and Gonil 2010; Wang et al. 2013; Liu et al. 2010; Liu et al. 2012). The broad peak between 18 and $19^{\circ}$ is an evidence of de-acetylation (Jang et al. 2004; Sagheer et al. 2009) and confirms that the treated samples are deacetylated chitin. The peaks between $20.5^{\circ}$ and $20.8^{\circ}$ are attributed to (020) of chitosan whereas the peaks between $26.3^{\circ}-26.6^{\circ}$ and $18^{\circ}-19^{\circ}$ are attributed to (013) and (110) of $\alpha$-chitin, respectively.

\section{Thermal properties of snail chitin}

Figures 10 and 11 show DTG and TGA curves for samples treated with $1.5 \mathrm{M} \mathrm{HCl}$. Samples were first subjected to degradation test between 25 and $1000{ }^{\circ} \mathrm{C}$ to check for the degradation of $\mathrm{CaCO}_{3}$ which usually occur between 600 and $800{ }^{\circ} \mathrm{C}$. As shown in Fig. 10 virgin snail shells show the degradation $(42.38 \%)$ of $\mathrm{CaCO}_{3}$ between 600 and $800{ }^{\circ} \mathrm{C}$. All treated samples did not show any degradation between 600 and $800{ }^{\circ} \mathrm{C}$ indicating that $\mathrm{CaCO}_{3}$ was completely removed during the treatment. After some confirmatory runs, it was decided that all treated samples be subjected to degradation between 25 and $750{ }^{\circ} \mathrm{C}$ temperature range. TGA curves of treated samples (Fig. 10) reveal that degradation occurs in two steps. This is in line with other studies reporting the extraction of chitin from other sources (Sagheer et al. 2009; La Juárez-de Rosa et al. 2012; Abdou et al. 2008). The first of these mass losses is attributed to evaporation of the water, and the second, to decomposition of the chitin structure (Wang et al. 2013; Paulino et al. 2006; Jang et al. 2004). The water content varied between 3.96 and $4.19 \%$ of the total mass depending on the treatment condition (Table 6). The mass loss is seen to increase with increase in alkali concentration.

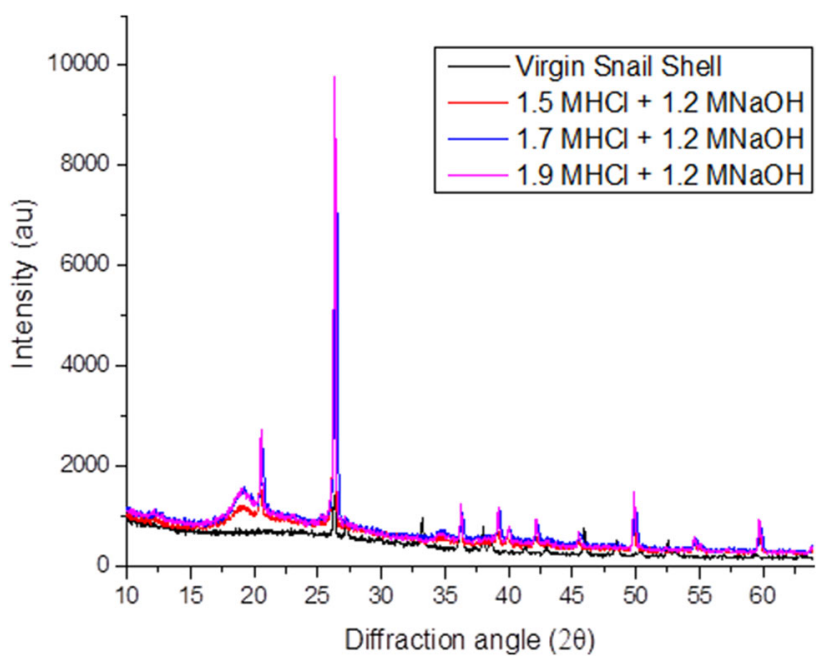

Fig. 9 XRD of chitin from snail shell
Table 5 Inter-sheet hydrogen bond energy for periwinkle shell chitin

\begin{tabular}{lllll}
\hline S/N & Sample & $\begin{array}{l}\mathrm{C}(6)-\mathrm{OH} \cdots \mathrm{OH}-\mathrm{C}(6) \\
\text { Bond energy (kcal) }\end{array}$ & $\begin{array}{l}\mathrm{C}(3)-\mathrm{OH} \cdots \mathrm{O}-\mathrm{C}(5) \\
\text { Bond energy (kcal) }\end{array}$ & $\begin{array}{l}\text { Average bond } \\
\text { energy (kcal) }\end{array}$ \\
\hline 1. & $1.5 \mathrm{M} \mathrm{HCl}+0.4 \mathrm{M} \mathrm{NaOH}$ & 8.29 & 2.64 & 10.93 \\
2. & $1.5 \mathrm{M} \mathrm{HCl}+0.8 \mathrm{M} \mathrm{NaOH}$ & 8.28 & 2.48 & 10.76 \\
3. & $1.5 \mathrm{M} \mathrm{HCl}+1.2 \mathrm{M} \mathrm{NaOH}$ & 8.30 & 2.58 & 10.88 \\
4. & $1.7 \mathrm{M} \mathrm{HCl}+0.4 \mathrm{M} \mathrm{NaOH}$ & 8.29 & 2.33 & 10.62 \\
5. & $1.7 \mathrm{M} \mathrm{HCl}+0.8 \mathrm{M} \mathrm{NaOH}$ & 8.26 & 2.45 & 10.71 \\
6. & $1.7 \mathrm{M} \mathrm{HCl}+1.2 \mathrm{M} \mathrm{NaOH}$ & 8.26 & 2.31 & 10.57 \\
7. & $1.9 \mathrm{M} \mathrm{HCl}+0.4 \mathrm{M} \mathrm{NaOH}$ & 8.28 & 2.38 & 10.66 \\
8. & $1.9 \mathrm{M} \mathrm{HCl}+0.8 \mathrm{M} \mathrm{NaOH}$ & 8.26 & 2.34 & 10.60 \\
9. & $1.9 \mathrm{M} \mathrm{HCl}+1.2 \mathrm{M} \mathrm{NaOH}$ & 8.26 & 2.36 & 10.62 \\
\hline
\end{tabular}




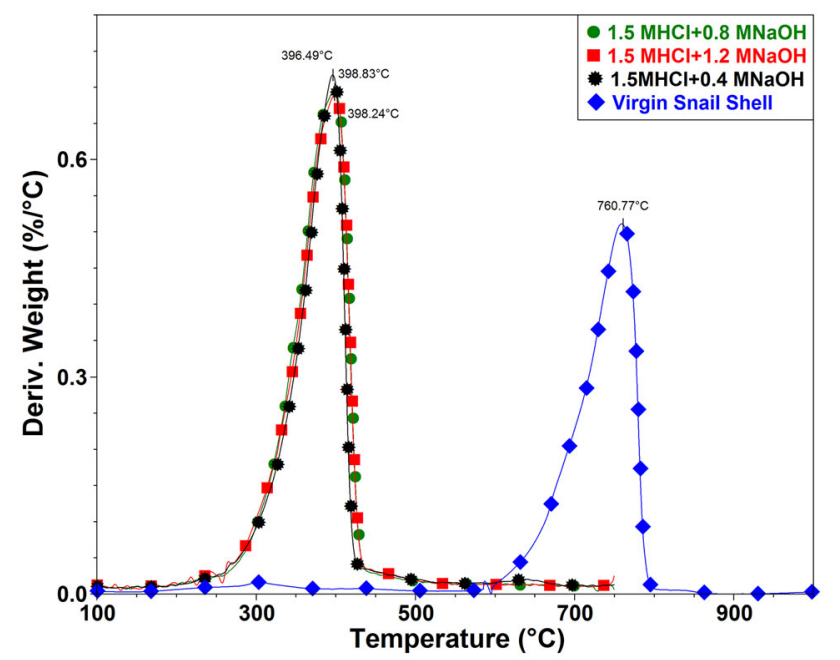

Fig. 10 DTG of snail chitin treated with $1.5 \mathrm{M} \mathrm{HCl}$ and varying alkali concentration (DTG for 1.7 and $1.9 \mathrm{M} \mathrm{HCl}$ treated samples are given in supplementary data file)

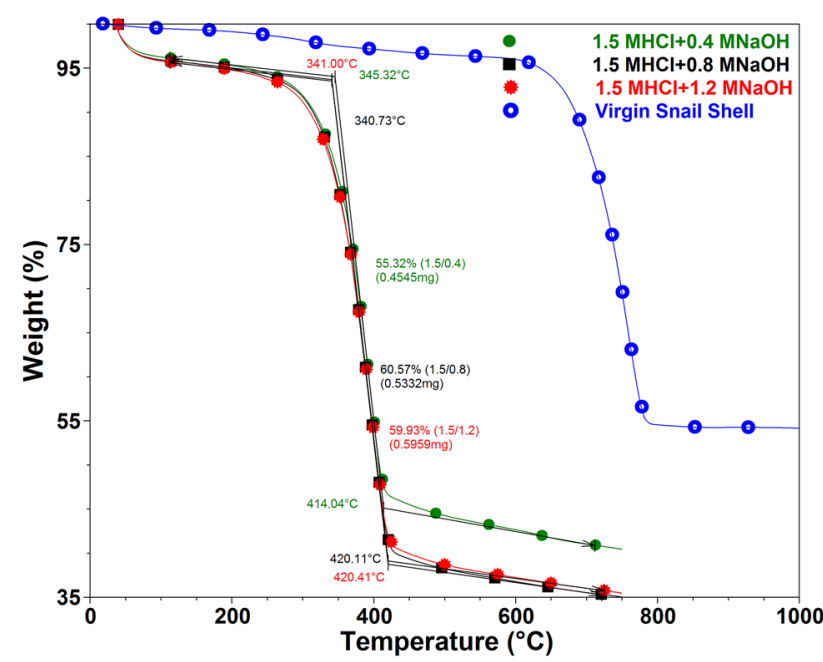

Fig. 11 TGA of snail chitin treated with $1.5 \mathrm{M} \mathrm{HCl}$ and varying alkali concentration (TGA for 1.7 and $1.9 \mathrm{M} \mathrm{HCl}$ treated samples are given in supplementary data file)
In the second step, the observed mass loss varied between 55 and $60 \%$ depending on treatment conditions (Table 6). The maximum mass loss $(60.57 \%)$ is observed in the $0.8 \mathrm{M} \mathrm{NaOH}$-treated sample whereas the minimum mass loss $(55.32 \%)$ is observed in $0.4 \mathrm{M} \mathrm{NaOH}$-treated sample. The DTGmax values $\left(396-398{ }^{\circ} \mathrm{C}\right)$, are similar for all treated samples (Table 6). Other authors, reported DTGmax value of alpha chitin to vary between 350 and $400{ }^{\circ} \mathrm{C}$ (Wang et al. 2013; Sajomsang and Gonil 2010; Kaya et al. 2014). The calculated activation energies for the treated samples are 24, 27 and $29 \mathrm{~kJ} \mathrm{~mol}^{-1}$ for $0.4,0.8$ and $1.2 \mathrm{M} \mathrm{NaOH}$-treated samples, respectively. This shows that increase in alkali concentration led to increase in thermal stability. The onsets of degradation for the samples are 345,340 and $341{ }^{\circ} \mathrm{C}$ for $0.4,0.8$ and $1.2 \mathrm{M} \mathrm{NaOH}$, respectively. These values are higher than those reported by Abdou et al. (2008), Gbenebor et al. (2016), Sagheer et al. (2009), Zawadzki and Kaczmarek (2010) and Shigemasa et al. (1996). The residue after $1000 \mathrm{C}$ is between 35 and $41 \%$ similar to that reported by Gbenebor et al. (2016) for crab and shrimp shell chitins. Table 6 summarizes the thermal properties for all the treated samples. A similar trend is noticed for each group with very minimal difference.

\section{Surface morphology of chitin extracted from snail shell}

Figure 12a is the SEM image of the virgin snail shell showing non-uniform particle size with rough surface. The EDS shows that the sample contains very high percentage of calcium. Treatment with $1.9 \mathrm{M} \mathrm{HCl}$ (see Fig. 12b) led to a change from rough to smooth surface. This is attributed to the removal of $\mathrm{CaCO}_{3}$. The EDS of this sample shows the absence of calcium. This indicates that calcium-related compounds were completely removed after demineralisation. Carbon and nitrogen increased indicating that brought about the development of chitin structure. On the other

Table 6 Thermal properties of snail shell chitin

\begin{tabular}{lllcccc}
\hline Sample & Activation energy & Residue at $600{ }^{\circ} \mathrm{C}$ & DTG2 & DTG1 & DTGmax & Onset Temp \\
\hline $1.5 \mathrm{M} \mathrm{HCl}+0.4 \mathrm{M} \mathrm{NaOH}$ & 24.31 & 40.72 & 55.32 & 3.96 & 396.32 & 345.32 \\
$1.5 \mathrm{M} \mathrm{HCl}+0.8 \mathrm{M} \mathrm{NaOH}$ & 27.20 & 35.24 & 60.57 & 4.19 & 397.91 & 340.73 \\
$1.5 \mathrm{M} \mathrm{HCl}+1.2 \mathrm{M} \mathrm{NaOH}$ & 29.08 & 35.73 & 59.93 & 4.34 & 398.90 & 341.00 \\
$1.7 \mathrm{M} \mathrm{HCl}+0.4 \mathrm{M} \mathrm{NaOH}$ & 93.92 & 34.19 & 56.85 & 8.96 & 360.81 & 319.33 \\
$1.7 \mathrm{M} \mathrm{HCl}+0.8 \mathrm{M} \mathrm{NaOH}$ & 56.62 & 33.23 & 55.50 & 11.27 & 371.18 & 332.46 \\
$1.7 \mathrm{M} \mathrm{HCl}+1.2 \mathrm{M} \mathrm{NaOH}$ & 34.93 & 30.51 & 59.80 & 9.69 & 380.86 & 335.45 \\
$1.9 \mathrm{M} \mathrm{HCl}+0.4 \mathrm{M} \mathrm{NaOH}$ & 28.03 & 36.32 & 57.71 & 5.97 & 384.12 & 338.98 \\
$1.9 \mathrm{M} \mathrm{HCl}+0.8 \mathrm{M} \mathrm{NaOH}$ & 25.66 & 47.27 & 48.13 & 4.60 & 393.40 & 341.28 \\
$1.9 \mathrm{M} \mathrm{HCl}+1.2 \mathrm{M} \mathrm{NaOH}$ & 27.66 & 42.57 & 51.97 & 5.46 & 397.43
\end{tabular}


Fig. 12 SEM images of snail shell chitin a untreated b Acid treated c $1.9 \mathrm{M} \mathrm{HCl} / 0.8 \mathrm{M}$

$\mathrm{NaOH}$ treated d $1.9 \mathrm{M} \mathrm{HCl} / 0.8$ $\mathrm{M} \mathrm{NaOH}$ treated
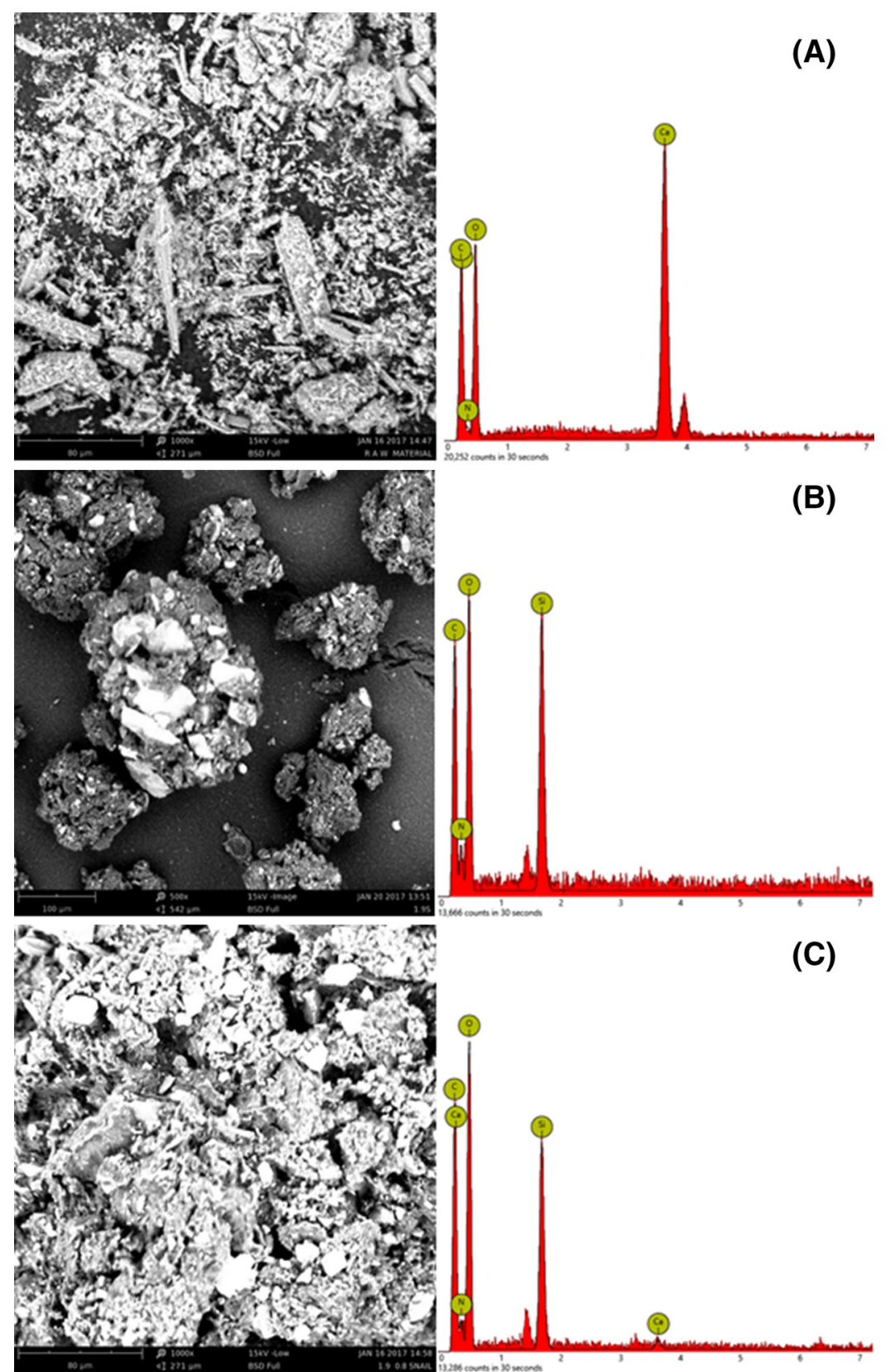

(C)

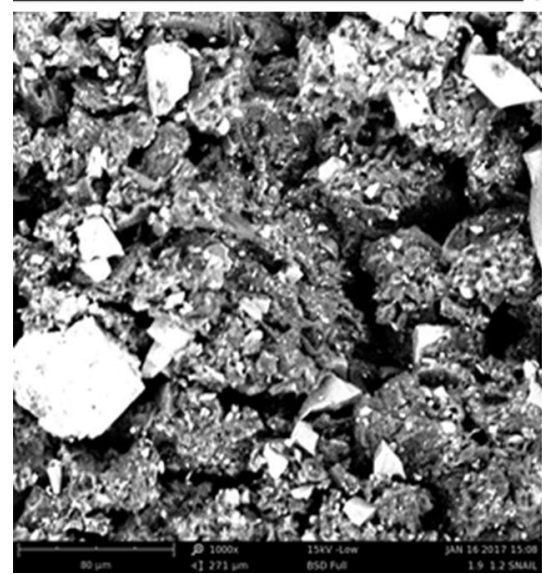

(D)

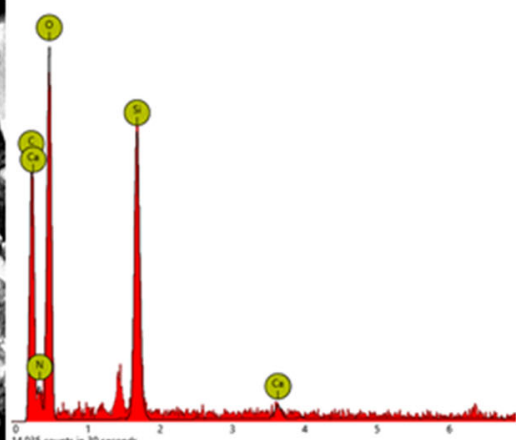


hand, the EDS shows that Si is present in the demineralised sample. This was not seen in the virgin sample. The presence of $\mathrm{Si}$ in crustacean shells has been reported by Isa et al. (2012). The globular white-like particles are identified as oxygen containing mineral compounds. EDS show that $\mathrm{Si}$ and oxygen are the major component of this particle. The dark-like particles are identified as carbon containing structures. Figure $12 \mathrm{c}$ shows the SEM images of $0.8 \mathrm{M}$ $\mathrm{NaOH}$-treated samples. The image shows a well arranged micro-fibrillar structure with no agglomeration. Further, increase in molar concentration of the alkali led to increase in the fibril size (see Fig. 12d).

\section{Conclusion}

Chitin has been extracted from periwinkle and snail shells using varying concentrations of acid and alkali.

1. The study shows that $\mathrm{CaCO}_{3}$ was completely removed from snail and periwinkle shells when $1.7 \mathrm{M} \mathrm{HCl}$ was used for demineralisation.

2. The Degree of deacetylation of the extracted chitin increases as the alkali concentration increases.

3. The study also reveals that the average inter-sheet hydrogen bond energy of the extracted chitin is strongly dependent on acid concentration.

4. It is also clear from the study that the degree of deacetylation is related to H-Bond energy.

5. The study also shows that extreme high level of the factors (acid and alkaline concentrations) leads to depolymerisation of the polysaccharide chains producing decline in DD and H-Bond.

6. Thermal properties of snail and periwinkle shell chitin are significantly affected by concentration of acid and alkali used in their extraction.

Acknowledgement The research group acknowledge with grateful thanks the University of Lagos for providing the University Research Grant (CRC NO.2015/19) used for this study. We are also grateful for the assistance provided by Department of Metallurgical and Materials Engineering, University of Lagos to use the Metallurgy Laboratory.

\section{Compliance with ethical standards}

Funding This study was funded by Central Research Council (CRC) of the University of Lagos, Lagos, Nigeria.

Conflict of interest All authors declare that they have no conflict of interest.

Ethical approval This article does not contain any studies with human or animals performed by any of the authors.

Open Access This article is distributed under the terms of the Creative Commons Attribution 4.0 International License (http:// creativecommons.org/licenses/by/4.0/), which permits unrestricted use, distribution, and reproduction in any medium, provided you give appropriate credit to the original author(s) and the source, provide a link to the Creative Commons license, and indicate if changes were made.

\section{References}

Abdou ES, Nagy KSA, Elsabee MZ (2008) Extraction and characterization of chitin and chitosan from local sources. Bioresour Technol 99(5):1359-1367. doi:10.1016/j.biortech.2007.01.051

Aku SY, Yawas DS, Madakson PB, Amaren SG (2012) Characterization of periwinkle shell as asbestos-free brake pad materials. Pac J Sci Technol 13(2):57-63

Al-Manhel AJ, Al-Hilphy ARS, Niamah AK (2016) Extraction of chitosan, characterisation and its use for water purification. J Saudi Soc Agric Sci. doi:10.1016/j.jssas.2016.04.001

Arof L, Subban R, Radhakrishna S (eds) (1995) Polymer and other advanced materials: emerging technologies and business. Plenum Press, New York

Cho Y-W, Jang J, Park CR, Ko S-W (2000) Preparation and solubility in acid and water of partially deacetylated chitins. Biomacromol 1(4):609-614. doi:10.1021/bm000036j

Domszy JG, Roberts GAF (1985) Evaluation of infrared spectroscopic techniques for analysing chitosan. Makromol Chem 186(8):1671-1677. doi:10.1002/macp.1985.021860815

Ehrlich H, Bazhenov VV, Debitus C, de Voogd N, Galli R, Tsurkan MV, Wysokowski M, Meissner H, Bulut E, Kaya M, Jesionowski $\mathrm{T}$ (2017) Isolation and identification of chitin from heavy mineralized skeleton of Suberea clavata (Verongida: Demospongiae: Porifera) marine demosponge. Int $\mathrm{J}$ Biol Macromol. doi:10.1016/j.ijbiomac.2017.01.141

Farajzadeh F, Motamedzadegan A, Shahidi S-A, Hamzeh S (2016) The effect of chitosan-gelatin coating on the quality of shrimp (Litopenaeus vannamei) under refrigerated condition. Food Control 67:163-170. doi:10.1016/j.foodcont.2016.02.040

Gbenebor OP, Adeosun SO, Lawal GI, Jun S (2016) Role of $\mathrm{CaCO}_{3}$ in the physicochemical properties of crustacean-sourced structural polysaccharides. Mater Chem Phys 184:203-209. doi:10. 1016/j.matchemphys.2016.09.043

Georgieva V, Zvezdova D, Vlaev L (2012) Non-isothermal kinetics of thermal degradation of chitosan. Chem Cent J 6:81. doi:10.1186/ 1752-153X-6-81

Gonil P, Sajomsang W (2012) Applications of magnetic resonance spectroscopy to chitin from insect cuticles. Int J Biol Macromol 51(4):514-522. doi:10.1016/j.ijbiomac.2012.06.025

Hamed I, Özogul F, Regenstein JM (2016) Industrial applications of crustacean by-products (chitin, chitosan, and chitooligosaccharides): A review. Trends Food Sci Technol 48:40-50. doi:10. 1016/j.tifs.2015.11.007

Hamdi M, Hammami A, Hajji S, Jridi M, Nasri M, Nasri R (2017) Chitin extraction from blue crab (Portunus segnis) and shrimp (Penaeus kerathurus) shells using digestive alkaline proteases from P. segnis viscera. Int J Biol Macromol 101:455-463. doi:10.1016/j.ijbiomac.2017.02.103

Heredia A, Aguilar-Franco M, Magaña C, Flores C, Piña C, Velázquez R, Schäffer TE, Bucio L, Basiuk VA (2007) Structure and interactions of calcite spherulites with $\alpha$-chitin in the brown shrimp (Penaeus aztecus) shell. Mater Sci Eng, C 27(1):8-13. doi:10.1016/j.msec.2005.11.003

Hu X, Du Y, Tang Y, Wang Q, Feng T, Yang J, Kennedy JF (2007) Solubility and property of chitin in $\mathrm{NaOH} /$ urea aqueous solution. Carbohyd Polym 70(4):451-458. doi:10.1016/j.carbpol.2007.05.002 
Isa MT, Ameh AO, Tijjani M, Adama KK (2012) Extraction and characterization of chitin and chitosan from Nigerian shrimps. Int J Bio Chem Sci. doi:10.4314/ijbcs.v6i1.40

Jang M-K, Kong B-G, Jeong Y-I, Lee CH, Nah J-W (2004) Physicochemical characterization of $\alpha$-chitin, $\beta$-chitin, and $\gamma$ chitin separated from natural resources. J Polym Sci A 42(14):3423-3432. doi:10.1002/pola.20176

Kameda T, Miyazawa M, Ono H, Yoshida M (2005) Hydrogen bonding structure and stability of alpha-chitin studied by $13 \mathrm{C}$ solid-state NMR. Macromol Biosci 5(2):103-106. doi:10.1002/ mabi.200400142

Kasaai MR (2009) Various methods for determination of the degree of $\mathrm{N}$-acetylation of chitin and chitosan: a review. J Agric Food Chem 57(5):1667-1676. doi:10.1021/jf803001m

Kaya M, Baran T (2015) Description of a new surface morphology for chitin extracted from wings of cockroach (Periplaneta americana). Int J Biol Macromol 75:7-12. doi:10.1016/j.ijbiomac. 2015.01.015

Kaya M, Sargin I, Tozak KÖ, Baran T, Erdogan S, Sezen G (2013) Chitin extraction and characterization from Daphnia magna resting eggs. Int J Biol Macromol 61:459-464. doi:10.1016/j. ijbiomac.2013.08.016

Kaya M, Baran T, Erdogan S, Mentes A, Ozusaglam MA, Cakmak YS (2014) Physicochemical comparison of chitin and chitosan obtained from larvae and adult Colorado potato beetle (Leptinotarsa decemlineata). Mater Sci Eng C Mater Biol Appl 45:72-81. doi:10.1016/j.msec.2014.09.004

Kaya M, Erdogan S, Mol A, Baran T (2015a) Comparison of chitin structures isolated from seven Orthoptera species. Int J Biol Macromol 72:797-805. doi:10.1016/j.ijbiomac.2014.09.034

Kaya M, Baran T, Asan-Ozusaglam M, Cakmak YS, Tozak KO, Mol A, Mentes A, Sezen G (2015b) Extraction and characterization of chitin and chitosan with antimicrobial and antioxidant activities from cosmopolitan Orthoptera species (Insecta). Biotechnol Bioproc E 20(1):168-179. doi:10.1007/s12257-0140391-z

Khan TA, Peh KK, Ch'ng HS (2002) Reporting degree of deacetylation values of chitosan: the influence of analytical methods. J Pharm Pharmaceut Sci 5(3):205-212

Kumirska J, Czerwicka M, Kaczynski Z, Bychowska A, Brzozowski K, Thoming J, Stepnowski P (2010) Application of spectroscopic methods for structural analysis of chitin and chitosan. Mar Drugs 8(5):1567-1636. doi:10.3390/md8051567

Kurita K, Nishimura S-I, Takeda T (1990) N-hydroxyacylation of chitosan with lactones. Polym J 22(5):429-434

Kurita K, Tomita K, Tada T, Ishii S, Nishimura S-I, Shimoda K (1993a) Squid chitin as a potential alternative chitin source: deacetylation behavior and characteristic properties. J Polym Sci A 31(2):485-491. doi:10.1002/pola.1993.080310220

Kurita K, Tomita K, Ishii S, Nishimura S-I, Shimoda K (1993b) $\beta$ chitin as a convenient starting material for acetolysis for efficient preparation of $\mathrm{N}$-acetylchitooligosaccharides. J Polym Sci A 31(9):2393-2395. doi:10.1002/pola.1993.080310923

Kurita K, Ishii S, Tomita K, Nishimura S-I, Shimoda K (1994) Reactivity characteristics of squid $\beta$-chitin as compared with those of shrimp chitin: high potentials of squid chitin as a starting material for facile chemical modifications. J Polym Sci A 32(6):1027-1032. doi:10.1002/pola.1994.080320603

La Juárez-de Rosa BA, Quintana P, Ardisson P-L, Yáñez-Limón JM, Alvarado-Gil JJ (2012) Effects of thermal treatments on the structure of two black coral species chitinous exoskeleton. J Mater Sci 47(2):990-998. doi:10.1007/s10853-011-5878-9

Liu T, Li B, Zheng X, Liang S, Song X, Zhu B, Kennedy JF, Xia J (2010) Effects of freezing on the condensed state structure of chitin in alkaline solution. Carbohyd Polym 82(3):753-760. doi:10.1016/j.carbpol.2010.05.047
Liu S, Sun J, Yu L, Zhang C, Bi J, Zhu F, Qu M, Jiang C, Yang Q (2012) Extraction and characterization of chitin from the beetle Holotrichia parallela Motschulsky. Molecules 17(4):4604-4611. doi:10.3390/molecules17044604

Maruthiah T, Palavesam A (2017) Characterization of haloalkalophilic organic solvent tolerant protease for chitin extraction from shrimp shell waste. Int J Biol Macromol 97:552-560. doi:10.1016/j.ijbiomac.2017.01.021

Mikkelsen A, Engelsen SB, Hansen HCB, Larsen O, Skibsted LH (1997) Calcium carbonate crystallization in the $\alpha$-chitin matrix of the shell of pink shrimp, Pandalus borealis, during frozen storage. J Cryst Growth 177(1):125-134. doi:10.1016/S00220248(96)00824-X

Minke R, Blackwell J (1978) The structure of $\alpha$-chitin. J Mol Biol 120(2):167-181. doi:10.1016/0022-2836(78)90063-3

Muzzarelli RAA (1997) Human enzymatic activities related to the therapeutic administration of chitin derivatives. Cell Mol Life Sci 53(2):131-140. doi:10.1007/PL00000584

Nair K, Madhavan P (1984) Chitosan for removal of mercury from water. Fish Technol 21(2):109-112

Paulino AT, Simionato JI, Garcia JC, Nozaki J (2006) Characterization of chitosan and chitin produced from silkworm crysalides. Carbohyd Polym 64(1):98-103. doi:10.1016/j.carbpol.2005.10.032

Peniche-Covas C, Alvarez LW, Arguielles-Monal W (1992) The adsorption of mercuric ions by chitosan. J Appl Polym Sci 46(7):1147-1150. doi:10.1002/app.1992.070460703

Petrenko I, Bazhenov VV, Galli R, Wysokowski M, Fromont J, Schupp PJ, Stelling AL, Niederschlag E, Stöker H, Kutsova VZ, Jesionowski T, Ehrlich H (2017) Chitin of poriferan origin and the bioelectrometallurgy of copper/copper oxide. Int J Biol Macromol. doi:10.1016/j.ijbiomac.2017.01.084

Rahman MA, Halfar J (2014) First evidence of chitin in calcified coralline algae: new insights into the calcification process of Clathromorphum compactum. Sci Rep 4:1-11

Ramasamy P, Subhapradha N, Thinesh T, Selvin J, Selvan KM, Shanmugam V, Shanmugam A (2017) Characterization of bioactive chitosan and sulfated chitosan from Doryteuthis singhalensis (Ortmann, 1891). Int J Biol Macromol 99:682-691. doi:10.1016/j.ijbiomac.2017.03.041

Rasti H, Parivar K, Baharara J, Iranshahi M, Namvar F (2017) Chitin from the mollusc Chiton: extraction, characterization and chitosan preparation. IJPR 16(1):366-379

Rudall KM, Kenchington W (1973) The chitin system. Biol Rev 48(4):597-633. doi:10.1111/j.1469-185X.1973.tb01570.x

Sagheer FA, Al-Sughayer MA, Muslim S, Elsabee MZ (2009) Extraction and characterization of chitin and chitosan from marine sources in Arabian Gulf. Carbohyd Polym 77(2):410-419. doi:10.1016/j.carbpol.2009.01.032

Sajomsang W, Gonil P (2010) Preparation and characterization of $\alpha$ chitin from cicada sloughs. Mater Sci Eng C 30(3):357-363. doi:10.1016/j.msec.2009.11.014

Shigemasa Y, Matsuura H, Sashiwa H, Saimoto H (1996) Evaluation of different absorbance ratios from infrared spectroscopy for analyzing the degree of deacetylation in chitin. Int $\mathbf{J}$ Biol Macromol 18(3):237-242. doi:10.1016/0141-8130(95)01079-3

Sikorski P, Hori R, Wada M (2009) Revisit of $\alpha$-chitin crystal structure using high resolution X-ray diffraction data. Biomacromol 10(5):1100-1105. doi:10.1021/bm801251e

Tan SC, Khor E, Tan TK, Wong SM (1998) The degree of deacetylation of chitosan: advocating the first derivative UVspectrophotometry method of determination. Talanta 45(4):713-719. doi:10.1016/S0039-9140(97)00288-9

Udomkan N, Limsuwan P (2008) Temperature effects on freshwater snail shells: pomacea canaliculata Lamarck as investigated by XRD, EDX, SEM and FTIR techniques. Mater Sci Eng C 28(2):316-319. doi:10.1016/j.msec.2007.03.001 
Usman A, Zia KM, Zuber M, Tabasum S, Rehman S, Zia F (2016) Chitin and chitosan based polyurethanes: a review of recent advances and prospective biomedical applications. Int J Biol Macromol 86:630-645. doi:10.1016/j.ijbiomac.2016.02.004

Wang Y, Chang Y, Yu L, Zhang C, Xu X, Xue Y, Li Z, Xue C (2013) Crystalline structure and thermal property characterization of chitin from Antarctic krill (Euphausia superba). Carbohydr Polym 92(1):90-97. doi:10.1016/j.carbpol.2012.09.084

Wanjun T, Cunxin W, Donghua C (2005) Kinetic studies on the pyrolysis of chitin and chitosan. Polym Degrad Stab 87(3):389-394. doi:10.1016/j.polymdegradstab.2004.08.006

Yen M-T, Yang J-H, Mau J-L (2009) Physicochemical characterization of chitin and chitosan from crab shells. Carbohyd Polym 75(1):15-21. doi:10.1016/j.carbpol.2008.06.006

Yuan Y, Chesnutt BM, Haggard WO, Bumgardner JD (2011) Deacetylation of chitosan: material characterization and in vitro evaluation via albumin adsorption and pre-osteoblastic cell cultures. Materials 4(12):1399-1416. doi:10.3390/ ma4081399

Zakaria Z, Izzah Z, Jawaid M, Hassan A (2012) Effect of degree of deacetylation of chitosan on thermal stability and compatibility of chitosan -polyamide blend. BioResources. doi:10.15376/ biores.7.4.5568-5580

Zawadzki J, Kaczmarek H (2010) Thermal treatment of chitosan in various conditions. Carbohyd Polym 80(2):394-400. doi:10. 1016/j.carbpol.2009.11.037

Zhang Y, Zhang X, Ding R, Zhang J, Liu J (2011) Determination of the degree of deacetylation of chitosan by potentiometric titration preceded by enzymatic pretreatment. Carbohyd Polym 83(2):813-817. doi:10.1016/j.carbpol.2010.08.058 